1991

\title{
Power Imbalances in Therapeutic and Forensic Relationships
}

Michael L. Perlin

New York Law School, michael.perlin@nyls.edu

Follow this and additional works at: https://digitalcommons.nyls.edu/fac_articles_chapters

Part of the Law and Psychology Commons

\section{Recommended Citation}

Perlin, Michael L., "Power Imbalances in Therapeutic and Forensic Relationships" (1991). Articles \& Chapters. 1118.

https://digitalcommons.nyls.edu/fac_articles_chapters/1118

This Article is brought to you for free and open access by the Faculty Scholarship at DigitalCommons@NYLS. It has been accepted for inclusion in Articles \& Chapters by an authorized administrator of DigitalCommons@NYLS. 


\title{
Power Imbalances in Therapeutic and Forensic Relationships
}

\author{
Michael L. Perlin, J.D.
}

\begin{abstract}
This article examines the ways that power imbalances affect relationships in the forensic mental disability system and between therapists and their clients. It considers the impact of the "dual loyalty" dilemma on forensic relationships, the manner in which courts deal with this dilemma, and suggests several points of commonality that arise around such power conflicts. It also examines recent litigation involving therapeutic relationships, and attempts to extract doctrinal threads from these cases. Finally, it recommends that, in order for the judicial system to attempt to correct any of the underlying imbalances, courts and jurors must openly come to grips with the psychodynamic issues that underlie these imbalances.
\end{abstract}

\section{INTRODUCTION}

The legal system is, at its base, about the allocation of power, ${ }^{1}$ and the existence of power relationships: relationships between the state and individuals, ${ }^{2}$ between the federal government and the states, ${ }^{3}$ and between the legislature and the judiciary. ${ }^{4}$ Almost every significant Supreme Court case involves questions dealing with power relationships, with the distribution of power and the limits of power. Consider

Micha

Michael L. Perlin, J.D., is Professor of Law at New York Law School. An earlier draft of this paper

Was presented at the University of Pennsylvania Department of Psychiatry Conference on Legal and

Ethical Issues in Mental Health, November 1990, Philadelphia, PA. The author wishes to thank Debbie

Dorfman for her helpful research assistance, Bob Sadoff and Alan Tomkins for their insightful suggestions,

Linda Perlin for helping me come to understand many of the underlying issues, and two anonymous

reviewers for their recommendations. Address reprint requests and correspondence to the author at New

York Law School, 57 Worth Street, New York, NY 10013, USA.

The argument is made most powerfully in Cover, Violence and the Word, 95 YALE L. J. 1601 (1986)

Cover's work is carefully considered in Sherwin, Law, Violence, and Mliberal Belief, 78 GEO. L.J. 1785

(1990).

The issue is discussed in, inter alia, Powell v. McCormack, 395 U.S. 486, 514 (1969) (power of

Cl.

Busik 1977), cert den., 434 U.S. 1009 (1978) (justiciability of case involving federal judge pay scale);

Busik v. Levine, 63 N.J. 351, 307 A.2d 571, 594 (1973), appeal dismissed, 414 U.S. 1106 (1973) (rule-

making power of state Supreme Court); People v. Kaeding, 98 Ill.2d 237, 456 N.E.2d 11, 17 (1983),

me $g$ den. (1983) (allocation of treatment power in cases involving defendants adjudicated "guilty but

mentally ill'). On the manner in which jurisdictional decisions reflect power allocations, see M. REDISH,

Federal JuRusdiction: TeNSIONS IN THE Allocation OF JUdicial PoWER (1980).

See infra notes 8-9.

See infra notes 7, 12

(c) $195-3936 / 91 / 020111-18 \$ 09.00$

1991 by John Wiley \& Sons, Ltd. 
variously the power of a President to seize a company's steel mill at a time of national emergency, ${ }^{5}$ the power of the federal courts to force states to desegregate their school systems or private business enterprises to desegregate their public facilities, ${ }^{6}$ the power of the federal courts to deprive state prosecutors of the ability to use evidence against a criminal suspect that was obtained by methods that violated the Constitution, ${ }^{7}$ the power of a state to interfere with a woman's right to reproductive autonomy ${ }^{8}$ or a couple's right to practice consensual sodomy in their home, ${ }^{9}$ the power of a President to shield certain documents from public view, ${ }^{10}$ the power of the federal courts to order state legislatures to reapportion, ${ }^{11}$ or the power of the states to impose the death penalty. ${ }^{12}$

In other less well-known contexts, courts and scholars have begun to critically examine the existence of inherent imbalances of power in certain other relationships; for instance, the relationship between a franchise dealer and a manufacturer, ${ }^{13}$ between an employer and an employee, ${ }^{14}$ between sexual offenders and child victims, ${ }^{15}$ between students and university administrators, ${ }^{16}$ between attorneys and clients, ${ }^{17}$ between clergy and penitents, ${ }^{18}$ and between criminal defendants and the prosecution. ${ }^{19}$ Others have expanded this inquiry to consider the imbalances in any cross-gender relationships, ${ }^{20}$ or, even, in the full range of all relationships that exist in "social reality." in those cases where one party is dependent on the other through underlying professional, personal or social associations. ${ }^{22}$

For the purposes of this article, I wish to focus specifically on power imbalance issues that flow from three specific kinds of cases: (1) the institutionalization of putatively mentally ill individuals, (2) the trial of mentally disabled criminal defendants, and (3) the legal regulation of mental health practice. While scholars variously couch their discussion of these cases in such terms as balancing the police power with due process, or police power with parens patriae interests, or professional auton-

\footnotetext{
${ }^{3}$ Youngstown Sheet \& Tube Co. v. Sawyer, 343 U.S. 579 (1952).

${ }^{6}$ Brown v. Board of Education, 349 U.S. 294 (1955); Heart of Atlanta Motel, Inc. v. United States, 379 U.S. 241 (1964).

${ }^{7}$ Miranda v. Arizona, 369 U.S. 186 (1962); Mapp v. Ohio, 367 U.S. 643 (1961).

${ }^{8}$ Roe v. Wade, 410 U.S. 1113 (1973).

${ }^{2}$ Bowers v. Hardwick, 478 U.S. 186 (1986).

${ }^{10}$ United States v. Nixon, 418 U.S. 683 (1974).

${ }^{11}$ Baker v. Carr, 369 U.S. 186 (1962).

${ }^{12}$ Compare Furman v. Georgia, 408 U.S. 238 (1972) (unconstitutionality of death penalty), to Gregg v. Georgia, 428 U.S. 153 (1976) (upholding constitutionaliry of death penalty statutes).

${ }^{13}$ Monmouth Chrysler-Plymouth, Inc. v. Chrysler Corp., 102 N.J. 485, 509 A.2d 161 (1986).

${ }^{14}$ Rudow v. NYC Commission on Human Rights, 123 Misc.2d 709, 474 N.Y.S.2d 1005 (Sup. Ct. 1984); General Drivers, Helpers \& Truck Terminal Employees v. City of St. Paul, 270 N.W.2d 877 (Minn. 1978).

${ }_{15}$ Mindlin, Child Sexual Abuse and Criminal Statutes of Limitation: A Model for Reform, 65 WASH. L. REV . 189 (1991).

${ }^{16}$ Matsuda, Public Response to Racist Speech: Considering the Victim's Story, 87 MICH. L. REv. 2320 (1989).

${ }^{17}$ In re Littleton, 719 S.W.2d 772 (Mo. 1986).

${ }^{18}$ State v. Dutton, 450 N.W.2d 189 (Minn. Ct. App. 1990).

19 Resnik, The Federal Rules in Practice: The Domain of Courts, 137 U. PA. L. REv. 2219 (1989).

${ }^{20}$ Bender, Gender Equality in the Legal Profession: Sex Discrimination or Gender Ineguality, 57 FORD. L. REV. 941 (1989).

${ }^{21}$ West, Progressive and Conservative Constitutionalism, 88 Mrch. L. Rev . 641 (1990).

${ }^{22}$ Coleman, Sex in Power Dependency Relationships: Taking Unfair Advantage of the "Fair Sex," 53 AlB. L. REv. 95, 96 (1988).
} 
omy with personal privacy rights, paring the competing values to their core reveals that these cases all reflect allocations of power.

Power allocations in these three general areas may manifest themselves in a myriad of concrete situations. For example, there are allocations between a committing agency and an individual who wishes to resist commitment, ${ }^{23}$ or between a state department of mental health and an institutionalized individual seeking either to vindicate her right to treatment or to interpose her right to refuse treatment, ${ }^{24}$ or between a prosecutor seeking to make use of a statement admitting to guilt by a mentally disabled defendant who wishes to resist its introduction into evidence (in that it does not reflect the product of a "free will") and that defendant, ${ }^{25}$ or between a forensic mental health professional wishing to testify as to a defendant's "future dangerousness" (thus making him amenable to capital punishment in certain jurisdictions) and the resisting defendant, ${ }^{26}$ or between a tort plaintiff charging her therapist with sexual manipulation and the therapist arguing that the patient's claims are nothing more than misplaced transference, ${ }^{27}$ or between an assault victim alleging that a therapist should have somehow prevented the assault and the perpetrator's therapist arguing that principles of confidentiality "trump" any duty to warn or protect. ${ }^{28}$

And yet, we tend to view these cases from very different perspectives. We characterize them as involving questions of professional autonomy, "turf" issues, public safety considerations and matters of competing fundamental constitutional interests. What We seem to skip over is how all of these cases involve questions of power. In some instances, they involve the power that a state can exert over a mentally disabled

${ }^{23}$ See Lessard v. Schmidt, 349 F. Supp. 1078 (E.D. Wis. 1972). The underlying issues are considered in this context in Bagby, The Deprofessionalization of Civil Commitment, 29 CAN. PsyCHOLoGIST 234 (1988), ${ }^{24}$ See Wyatt v. Aderholt, 503 F.2d 1305 (5th Cir. 1974). (right to treatment); Youngberg v. Romeo, 457 U.S. 307 (1982) (right to freedom from bodily harm); Rennie v. Klein, 720 F.2d 266 (3d Cir. 1983) (right of civil patients to refuse treatment); Washington v. Harper, $110 \mathrm{~S}$. Ct. 1028 (1990) (right ${ }_{25}$ prisoner to refuse treatment).

${ }^{25}$ See Colorado v. Connelly, 479 U.S. 157 (1986).

${ }_{27}$ See Barefoot v. Estelle, 463 U.S. 880 (1983).

28 See Landau v. Werner, 105 Sol. J. 1008 (C.A. 1961).

See Tarasoff v. Regents of the University of California, 17 Cal.3d 425, 551 P.2d 334, 131 Cal. Rptr. 14 (1976).

In this context, the word "trump" is used to denote the supremacy of one right or duty over another zight or duty. See, e.g., Tahoe-Sierra Preservation Council, Inc. v. Tahoe Reg'l Planning Agency, 911

F.2d 1331, 1347 ( 9 th Cir. 1990) (Kozinski, J., dissenting in part):

The fact is, the Constitution protects a variety of rights and liberties and reasonable minds might differ as to the relative importance of each. When we relegate certain of these to collateral status by refusing to give them the full measure of constitutional protection, we undermine the integrity of the constitutional structure and hand a potent weapon to those who may not share our vision as to which rights trump which.

See also Dworkin, What Is Equalivy? Part 3: The Place of Liberty, 73 lowa L. REv. 1, 13 n.11 (1987)

("a utilitarian political morality could not recognize a general right to liberty as a trump over utilitarian calculations of overall social advantage"). The principle is applied in, inter alia, IRS v. Federal Labor Relations Authority, 110 S. Ct. 1623, 1627 (1990) (labor-management grievances); Lamb v. Phillip Morris, Inc., 915 F.2d 1024, 1029 n. 12 (6th Cir. 1990) (legislative history analysis); West-Texas Transmission, L.P. v. Enron Corp., 907 F.2d 1554, 1559 (5th Cir. 1990) (gas pipeline repurchase) Walker v. City of Kansas City, Mo., 911 F.2d 80, 95 (8th Cir. 1990) (ordinance regulating "go-go" bars); Perite, The "Rule of Reason" in Antitrust Law: Property Logic in Restraint of Competition, 40 HasTrNGs

L.J. 285 (1989) (antitrust implications of railroad stock purchase). 
individual, but they also involve the question of the exertion of power by a mental health professional over a mentally disabled individual.

The fact that these issues involve power allocations is enormously important. What is perhaps even more important is the fact that the whole question of power-of power balances and imbalances, of the use and exploitation of power, of the inevitability of power relationships-is so underdiscussed and underconsidered in this particular context. If Jonas Robitscher was correct when he argued a decade ago that the psychiatrist is the "most important nongovernmental decisionmaker in modern life," ${ }^{\prime 29}$ and if Alfred Adler was correct when he argued that the drive for power was the single most important factor in determining man's behavior, ${ }^{30}$ mental health professionals and the public at large both have to reflect on the special irony we face here. While we professionally understand fully the importance of power, while we politically know that mental health professionals have the capacity to exert tremendous power, and while we legally see that so many of the questions with which we deal in this area are bottomed on allocations of power, the basic power questions that pervade all of these relationships are still rarely explored. ${ }^{31}$

I will attempt to consider these questions in the following manner. In the section on Forensic Relationships, I will look at power balances and imbalances that are peculiar to the forensic relationship, adopting, for these purposes, Paul Appelbaum's limiting definition, construing such forensic relationships to apply to interactions the purpose of which "is to convey information to one or more third parties concerning the subject of the evaluation." ${ }^{32}$ I will consider briefly the dilemmas of "dual loyalties" first articulated 16 years ago by Jerome Shestack, ${ }^{33}$ the way some of the conflicts are treated by the courts, and the way some thoughtful forensic mental health professionals have suggested that the underlying problems can be dealt with.

In the section on Therapeutic Relationships, I will look at both global and specific power imbalances that stem from the therapeutic relationship. In conclusion, I will examine judicial attitudes towards the underlying issues, in an effort to try to determine whether there is any sort of doctrinal coherence to this whole area, explain the types of reasoning processes that seem to animate judicial decisionmakers here, and predict expected future developments.

\footnotetext{
${ }^{29}$ See J. Robitscher, The Powers of Psychiatry 8 (1980). See also Brodsky, Ethical Issues For Psychologisss in Corrections, in WhO Is THE CLIENT? THE ETHICS OF PSYChOLOGICAL INTERVENTION INTO THE CRIMINAI JUSTICE SYSTEM 63, 74 (J. Monahan ed. 1980) (discussing potential for abuse in "the considerable power that exists in psychology for controlling and shaping individuals' behavior').

${ }^{30}$ A. AdLER, The PRACTICE AND TheORY OF INDIVIDUAL PSYCHOLOGY 209 (A. Radin trans. 1951), as guoted in S. HLLLECK, THE PolITICS OF THERAPY 261 (1971).

${ }^{31}$ For instance, in neither of two of the most important contemporary psychiatric works on ethical issues in this field is there even a subject matter listing in the index for "power" or "coercion." See LaW

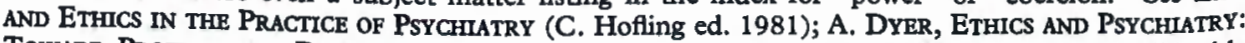
Toward Professtonal DefintTion (1985). Only one reference is made in Dyer's book to "double agentry." A. DYER, supra, at 68-69. See infra text accompanying notes 45-46. A WESTLAW ${ }^{\oplus}$ computer search (conducted on November 15, 1990) revealed only one civil case litigated in the last decade that deals directly with the underlying questions: an opinion that considered whether a state hospital could ban a parent from speaking to his institutionalized daughter where the facility's doctors believed that such communication conficted with the therapy being employed. See Doe v. Public Health Trust of Dade County, 696 F.2d 901 (11th Cir. 1983), holding that the hospital's non-communication policy "trumped" the parent's right to communicate with his child.

${ }^{32}$ Appelbaum, Confidentiality in the Forensic Evaluation, 7 INT'L J. L. \& PsYCHIATRY 285, 289 (1984).

${ }^{33}$ See Shestack, Pychiatry and the Dilemmas of Dual Loyalties, 60 A.B.A. J. 1521 (1974).
} 


\section{FORENSIC RELATIONSHIPS}

The most modest deconstruction ${ }^{34}$ of the phrase "forensic relationship" reveals the presenting dilemma: by its very nature, the "forensic relationship" is an unbalanced one. The forensic mental health professional is not, after all, "seeing a patient" for therapeutic purpose. Instead, she is intervening on behalf of the litigation, economic or administrative needs of one of a series of third parties-an attorney, the court, a prosecuting agency, a state mental health facility, an insurance company, an army. But for these external actors, the forensic relationship would not-could not-exist. ${ }^{35}$ There can be no pretense, for instance, (1) that absolute confidentiality applies at the forensic interview, ${ }^{36}$ or (2) that the mental health professional is present to provide treatment. ${ }^{37}$

Having said that, however, the inquiry into these two distinctions cannot come to an end. The mere fact that absolute confidentiality does not apply does not end consideration of that question; it is necessary for the evaluator to realize that the subject might still have legitimate expectations of confidentiality beyond what must be disclosed as within the material scope of the evaluation, ${ }^{38}$ and that the subject is entitled to be informed of the level of confidentiality that will apply in the forensic relationship. ${ }^{39}$ Beyond the threshold question of whether the interviewee is competent to give informed consent to a clinical assessment, ${ }^{40}$ collateral confidentiality questions must also be weighed by the evaluator: has the interviewee consented to the evaluation (in those instances where concepts of informed consent apply) ? ${ }^{41}$ Has the interviewer considered whether she has an obligation of reciprocity (that is, should she, can she, must she) tell the interviewee about information that she has gleaned from third parties? ${ }^{42}$ Answers to these dilemmas are rarely spelled out in case law or in statutes, and it is important that the forensic evaluator realize that she may have to answer them.

This relationship may still contain therapeutic content. If the legal relationship

\footnotetext{
${ }^{34}$ I have recently tried other similarly modest deconstructions in other areas of mental disability law.

See, e.g., Perlin, Are Courts Competent to Decide Competency Questions: Stripping the Facade from United States v. Charters, 38 U. KAN. L. REv. 957, 967-68 (1990) (deconstructing "competency"); Perlin, Competency, Deinstitutionalization, and Homelessness: A Story of Marginalization, 28 Hous. L. REv, 63 (1991) (Perlin, Competency) (same); M. Perlin, "Morality and Pretextuality, Psychiatry and Law: of 1990 ary Common Sense,' Heuristic Reasoning, and Cognitive Dissonance" (paper delivered to the 1990 annual conference of the American Academy of Psychiatry and Law) (deconstructing "pretextuality" in mental disability law and litigation).

${ }^{35}$ Weiner, Ethical Issues in Forensic Psychiatry: From an Atromey's Perspective, 12 BULL. AM. ACAD. PSYCHITRY \& L. 253, 254 (1984).

of "self-scrum, supra note 32, at 287-90. In a related vein, Herbert Modlin points out that the exercise

frequen-scrutiny" is especially important to forensic psychiatrists, whose opinions and conclusions "are

Psychtly subject to public scrutiny." Modlin, Forensic Psychiatry and Malpractice, 18 BuLL. AM. ACAD.

${ }^{39}$ WCHIATRY \& L. 153, 162 (1990).

Weiner, supra note 35 , at 253-54.

${ }^{30}$ Appeibaum, supra note 32, at 289-90.

Report of the Task Force on the Role of Psychology in the Criminal Justice System, in J. Monahan, ed., supra note 29, at 1, 5. Monahan's inquiry is considered carefully in Lyon \& Levine, Ethics, Power,

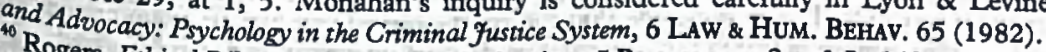

${ }^{40}$ Rogers, Ethical Dilemmas in Forensic Evaluations, 5 BEravioral SCI. \& L. 149, 154 (1987).

12 See . Monahan, supra note 29, at 6-7.

The Applisupra note 40, at 155-56. On the implications of Tarasoff for forensic relationships, see Note, The Application of the Tarasoff Duty to Forensic Psychiarry, 66 VA. L. REv. 715 (1980).
} 
and the due process hearing have a therapeutic content ${ }_{3}^{43}$ it would be unseemly to suggest that contact with an evaluating mental health professional is definitionally devoid of such content. The fact that there may be some therapeutic content "raises the ante" as to force an assessment of whether the presence of this content may be inherently meretricious. Regardless, the potentiality of this presence cannot obscure some of the fundamental characteristics that are unique to the forensic relationship.

Indeed, given the omnipresence of a third party, it is necessary to begin with the proposition that, definitionally, any forensic relationship contains a power imbalance, because of the pervasive dangers of "dual loyalties," " or, more provocatively, of "double agentry." While the dangers stemming from this dual role may be different in differing circumstances (depending in large part on the motives of the forensic mental health professional's employer), the question to be asked is the same one first asked by Shestack:

Can the psychiatrist be both the agent of the patient and of the institution that employs him? [W] hom is the psychiatrist supposed to represent? ${ }^{46}$

Again, we can identify a plethora of conflict-laden situations: ${ }^{47}$

-a doctor employed by a public hospital interviewing an individual who faces civil commitment or an NGRI acquittee who is petitioning for release;

-a court clinic mental health professional examining defendants prior to the imposition of sentence;

-a psychiatrist on contract to an insurance company examining beneficiaries who allege psychic stress or trauma;

-a school district mental health professional who evaluates a "problem" student to determine whether suspension or expulsion or transfer is the appropriate disposition;

\footnotetext{
${ }^{43}$ See, e.g., Perlin, An Invitation to the Dance: An Empirical Response to Chief Fustice Warren Burger's "Time-Consuming Procedural Minuets" Theory in Parham v. F.R., 9 Bull. AM. ACAD. Psychiatry \& L. 149 (1976). Legal scholars are now beginning to critically investigate the question of how seriously (if at all) legal rules impair the functioning of the mental health system. See, e.g., Schopp \& Wexler, Shooting Yourself in the Foot With Due Care, 17 J. Psychiatry \& L. (1989); THERAPEUTIC JURISPRUDENCE: The LaW as a Therapeutic Agent (D. Wexler ed. 1990). For a recent listing of the relevant literature, see Winick, Comperency to Consent to Treatment: The Distinction Between Assent and Objection, 28 Hous. L. REv. n. 150 (1991).

${ }^{44}$ Shestack, supra note 33 , at 1521.

${ }^{45}$ Halleck, The Ethical Dilemmas of Forensic Psychiatry: A Utilizarian Approach, 12 BuLl. AM. ACAD. PsyCHIATRY \& L. 279, 279 (1984).

The most pointed judicial exchange on this issue is found in United States v. Byers, 740 F.2d 1104 (D.C. Cir. 1984) (Scalia, J.), on the question of the admissibility of statements made by a defendant to a court-appointed psychiatrist tending to negate his insanity defense. Compare id. at 1115 (no violation of defendant's right against self-incrimination when defendant raised insanity defense), to id. at 1152-53 (Bazelon, J., dissenting):
}

The government psychiatrist is armed with the same technical expertise as the private psychiatrist. He is trained to gain the confidence of a patient. As a medical doctor, the psychiatrist is conceived of as a healer, a participant in a voluntary theraperitic alliance directed to the patient's benefit. Unlike the policeman, whose goals and methods engender wariness in the defendant, the government psychiatrist in the state hospital engenders trust. But this trust is unwarranted. The psychiatrist's aim is diagnosis, not therapy. His primary commitment is to his institution, not to his patient. Given these concerns, I must conclude that the court-ordered psychiatrist examination poses a threat of coercion similar to that in the interrogation deemed unconstitutional in Miranda.

(footnotes omitted).

${ }^{46}$ Shestack, supra note 33, at 1521.

${ }^{47}$ See generally Halleck, supra note 45, at 280 . 
-the army psychiatrist examining a "troublemaker" soldier who faces a "Section 8" discharge;

-the private hospital doctor in a for-profit facility being pressured to maintain census levels;

- a forensic witness evaluating defendants for purposes of sentencing in potential death penalty cases (or, perhaps, testifying on the basis of hypotheticals in such matters), for purposes of evaluating competency to stand trial, or for purposes of evaluating criminal responsibility;

-a prison psychiatrist weighing a prisoner's right to refuse the imposition of psychotropic medication; or even,

-an examining witness retained by an attorney for a civil plaintiff or a criminal defendant whose opinion is sought either as to a question of competency, or as to the question of the presence of damages in a "psychiatric tort" case, or as to the viability of a mental status defense.

All of these disparate situations include some important points in common. First, there is a multiplicity of interests being represented. Beyond the potentially conflicting interests of the forensic mental health professional's employer, and the additional set of variables to be considered in weighing the specific ethical proscriptions for lawyers dealing with forensic experts, ${ }^{48}$ the forensic evaluator may also weighconsciously or unconsciously - community, social and political values (for example, in determining whether a notorious insanity acquittee should be given conditional release), ${ }^{49}$ or the availability of public hospital space or potential fear of liability in weighing the need for involuntary civil commitment. ${ }^{50}$ Ben Bursten sees the problem even more broadly. In his view, any decision as to whether any behavior is a product of mental illness is not a matter of scientific expertise, "but a matter of social policy."

This was conceded in a report done by an NIMH advisory committee in the wake of the Hinckley acquittal, acknowledging that, "in controversial cases," the government "can be counted upon to oppose any conditional release recommendation. ${ }^{952}$ In the civil context, we are now also beginning to consider seriously how patients' families feel about civil commitment; since early empirical surveys show that relatives now dramatically favor longer terms of commitment and less restrictive commitment standards and that they specifically express the need for the "assignment of a professional" to aid them in coping with their family member's commitment procedures, ${ }^{53}$ it is likely that this additional, potentially conflicting interest will also raise questions of further forensic imbalances.

Second, it is possible that the individual at risk may suffer harm as a result of his participation in the evaluation process. This is most pointed in the situation

See Fitch, Petrella \& Wallace, Legal Ethics and the Use of Mental Health Experts in Criminal Cases,

5 BeHaviorai. SCI. \& L. 105, 109-16 (1987).

${ }^{49}$ See Shestack, supra note 33, at 1522.

${ }^{30}$ Thompson \& Ager, An Experimental Analysis of the Civil Commitment Recommendations of Psychologists and Psychiatrists, 6 BEHAVIORAL SCI. \& L. 119, 120 (1988).

${ }^{51}$ B. BURSTEN, BEYOND PSYCHLATRIC EXPERTISE 167 (1984).

${ }^{32}$ Perlin, Unpacking the Myths: The Symbolism Mythology of Insanity Defense Jurisprudence, 40 CASE WES.

RES. L. REv. 599, 671 (1989-90), quoting Final Report of the National Institute of Mental Health Ad

Hoc Forensic Advisory Panel, 12 MENTAL \& PHYsical DisabiL ITY L. REP. 77, 96 (1988) (emphasis added).

${ }^{53}$ McFarland, Faulkner, Bloom, Hallaux \& Bray, Family Members' Opinions About Civil Commitment,

41 Hosp. \& COMMUNITY PsYchiatRY 537, 539 (1990). 
where a forensic expert evaluates a defendant to determine whether he is competent to be executed ${ }^{54}$ and it is in this context that forensic professionals have begun to debate whether they should be involved at all in the underlying process. ${ }^{55} \mathrm{How}$ ever, the potential for harm (albeit, lesser harm) to the subject in virtually every other forensic context should also be clear.

Third, some of the harm that may befall the patient may flow directly from the mental health professional's employment of skills designed to help individuals (and thus the earlier caveat as to how the interaction's "therepeutic content" may "raise the ante" for the patients). As Dr. Seymour Halleck has asked: "Is it morally justified to use skills originally developed for the sole purpose of helping patients in order to derive information that ultimately may be used to hurt them?"56 During the data-gathering process, the mental health professional may thus use his empathic skills to "seduce the subject into revealing deleterious information" he might not otherwise reveal. ${ }^{57}$

Fourth, unless the mental health professional acknowledges (consciously and openly) the existence of this potentially tainted relationship, it is likely that power imbalances will tilt even further to the institutional side. As an example, the recent United States Supreme Court case of Buchanan v. Kentucky ${ }^{58}$ allowed a prosecutor to rebut an "extreme emotional disturbance" defense by using the contents of a report prepared as part of a determination as to whether a pre-trial detainee was eligible for transfer to a hospital setting so as to be psychiatrically treated. Use of the report was sanctioned, notwithstanding the fact that the defendant had not been informed that data he gave to evaluators in determining his amenability to treatment might be used against him in the prosecution of the underlying homicide case. ${ }^{59}$ Again, if the subject is not informed fully of the imbalance in the "relationship" with the forensic examiner, decisions such as Buchanan will be inevitable.

Fifth, there exists an "identification bias" through which, as a result of a witness's unconscious identification with one "side" of a legal battle or his more conscious identification with a particular value system or set of ideological leanings, his "secret hope for victory for his own opinion [may lead to] innumerable subtle distortions

\footnotetext{
${ }^{34}$ Compare Ford v. Wainwright, 477 U.S. 399 (1986) (execution of a mentally ill prisoner violates the Eighth Amendment), to Penry v. Lynaugh, 109 S. Ct. 2934 (1989) (Eighth Amendment does not require blanket ban proscribing execution of mentally retarded prisoners). See also Perry v. Louisiana, $111 \mathrm{~S}$. Ct. 449 (1990), which vacated and remanded the Louisiana Supreme Court's decision allowing the State to administer antipsychotic medication to a death row inmate so as to make him competent to be executed, in light of the Court's decision in Washington v. Harper, 110 S. Ct. 1028 (1990) (articulating limits on right of prisoners to refuse antipsychotic medication). See generally 3 M. PERLIN, MENTAL Disability LAW: Crvil AND CRIMINAL \$17.02-17.06 (1989) \& \$17.06A (1990 pocket part).

${ }_{35}$ Compare Bonnie, Dilemmas in Administering the Death Penaly: Conscientious Abstention, Professional Ethics, and the Needs of the Legal System, 14 LAW \& HUM. BeHAV. 67 (1990), to Brodsky, Professional Ethics and Professional Morality in the Assessment of Competence for Execution, 14 LAW \& HuM. BEHAV. 91 (1990), to Bonnie, Grounds for Professional Abstention in Capital Cases: A Reply to Brodsky, 14 LAW \& HuM. BEHAV. 99 (1990).

${ }^{86}$ Halleck, supra note 45 , at 280.

${ }^{57}$ Appelbaum, Psychiatric Ethics in the Courtroom, 12 Burl. AM. ACAD. PsychIaTRY \& L. 225, 229 (1984).

${ }^{58} 107$ S. Ct. 2906 (1987).

${ }^{99}$ The relationship between Buchanan and Estelle v. Smith, 451 U.S. 454 (1981) (applying Fifth and Sixth Amendments to uncounseled pretrial psychiatric examination in case where insanity defense was not raised) is explored in $3 \mathrm{M}$. PerLIN, supra note 54, $\$ 16.04 \mathrm{~A}$, at 425-29, 434-35, and in Perlin, Admissibility of Psychiatric Evaluations Under Miranda and the Right to Counsel: Satterwhite and Buchanan, 15 SEARCH \& SEIZURE L. REP. 73 (1988).
} 
and biases in his testimony that spring from this wish to triumph." we find a positive influence of political ideology in forensic examiners' assessments of insanity defense claims ${ }^{61}$ and of civil psychic trauma allegations, ${ }^{62}$ an influence that has to be considered in light of the possibility that, in a whole variety of factsettings, social bias frequently "infects and hides behind scientific judgments."63 Recently, for instance, a research study revealed that a patient's sex, color and sexual orientation may control, to a significant degree, whether a physician decides to breach confidentiality and reveal that a patient carries the AIDS virus. ${ }^{64}$ The problem here is heightened when we consider the evidence that (1) many forensic experts misunderstand the basic relevant standards for such legal constructs as "insanity" or "incompetency to stand trial," are often unclear as to the express purpose for which the evaluation was sought in the first place. ${ }^{66}$

Sixth, there may be economic issues to consider as well. There is already some evidence that the recent dramatic increase in for-profit private psychiatric hospitals under corporate ownership has led to an increased number of children admitted to such facilities at a time when some physicians are under pressure to maintain a maximal census and thus increase profits. ${ }^{67}$ The potential that this pressure can distort forensic evaluations on questions of hospital admissions and releases is yet another power imbalance that we need to confront.

Seventh, we must consider recent evidence demonstrating that, in response to legislative actions tightening involuntary civil commitment criteria, some forensic mental health professionals answered by suggesting that such legal mandates could comfortably be ignored ${ }^{68}$ where they conflicted with the witness' "moral judgment," where they were "tyrannical," or where they would lead to a too "literal" interpretation of the law. ${ }^{69} \mathrm{Dr}$ William McCormick, for instance, has quoted an anonymous

\footnotetext{
${ }^{60}$ Diamond, The Fallacy of the Impartial Expert, 3 ARCHIVES CRIM. PsYchodnNAMICs 221, 222 (1959), as quoted in Goldstein, Hiring the Hired Guns: Lawyers and Their Psychiatric Experts, 11 LEGAL Stud. Forum 41 (1987); see also M. Perlin, supra note 34, manuscript at 13.

${ }^{61}$ See, e.g., Homant \& Kennedy, Fudgment of Legal Insanity as a Function of Attitude Toward the Insaniry Defense, 8 INT'L J. L. \& Psychitrity 67 (1985).

${ }^{62}$ Zusman \& Simon, Differences in Repeated Psychiatric Examinations of Litigants to a Lawsuit, $140 \mathrm{AM}$. J. PSYChIATRY 1300, 1302-04 (1983).

${ }^{63}$ Davis, Law, Science and History: Reflections Upon In The Best Interests of the Child., 86 MrcH. L. REV. 1096, 1107 (1988), citing S. Gould, THE MISMEASURE OF MAN 21-22 (1981).

${ }^{64}$ Physician Biases Found to Affect Decision to Maintain Patient Confidentiality, Psychutric News, Oct. 5,1990 , at 17 (research sample included 200 family practitioners, internists, obstetricians/gynecologists and general practitioners residing in Tennessee).

${ }^{65}$ Rogers, Turner, Heifield \& Dickens, Forensic Psychiatrists' and Psychologists' Understanding of Insantiy: Misguided Expertise, 33 CAN. J. PsYCHIATRY 691 (1988).

${ }_{67}^{60}$ Halleck, supra note 45 , at 281.

${ }^{67}$ Dalton \& Foreman, Conflicts of Interest Associated with the Psychiatric Hospitalization of Children, 57

AM. J. ORTHOPSYChIATRY 12, 13 (1987); see generally Schlesinger \& Dorwart, Ownership and Mental Health Services, 311 NEW ENG. J. MED. 959 (1984).

${ }^{6 B}$ This is not to suggest that all evaluators responded in this way. Compare Lidz, Mulvey, Appelbaum \& Cleveland, Commitment: The Consistency of Clinicians and the Use of Legal Standards, 146 AM. J. PSYCFIATRY 176 (1989) (in one carefully controlled test, clinicians did conform to the prevailing involuntary civil commitment law).

${ }^{69}$ See Chodoff, Involuntary Hospitalization of the Mentally Ill as a Moral Issue, 141 AM. J. PsYchiatRY 384, 388 (1984); Chodoff, The Case for Involuntary Hospitalization of the Mentally IIl, 133 AM. J. PSYCHIATRY 496, 501 (1976); Lamb, Involuntary Treatment for the Homeless Mentally Ill, 4 NOTRE DAME J. L. ETHICS \& PUB. PoL'Y 269, 277 (1989). Studies demonstrating that involuntary civil commitment decisionmaking "may not rest on statutory grounds" are collected in Thompson \& Ager, supra note
44, 120 .
} 
(but apparently knowledgeable) medical colleague who reported, following amendments to Ontario's Mental Health Act, "Doctors will continue to certify those whom they really believe should be certified. They will merely learn a new language.,"70 It was, in part, attitudes such as these that had led Michael Saks to refer to such witnesses as "imperial experts" who install themselves as "temporary monarchs" by replacing a "societal preference" expressed "through the law and legal process with [their] own preferences." benign setting: Paul Appelbaum has noted how, given the "extremely nebulous" standards set out in Social Security or Supplemental Security Income (SSI) disability law, there is "strong temptation" for sympathetic evaluators to call a patient disabled "even if that requires "twisting the rules of justice and fairness." ",72 It should be no surprise that such attitudes will likely lead to even more disproportionate forensic imbalances.

These imbalances turn up in a variety of dual loyalty institutional settings. In some cases, the "competitor" may be a mental health agency, an arm of state government, a private corporation, or a judicial agency. In each instance, the focus of the competing institutional loyalty is slightly different, but the same questions need to be asked:

Are clinicians unduly biased by agency? Do forensic experts engage in either self-deception and/or conscious misrepresentation regarding whom they see as the client? Does agency necessarily compromise objectivity? ? $^{73}$

While some prominent and thoughtful mental health professionals have responded nobly to the presence of this dilemma, ${ }^{74}$ this issue appears to be "off the table" for the purposes of most considerations of the forensic mental health system.

Finally, it should be intuitive that the tensions in these cases are increased once the underlying matter actually reaches the courtroom. And yet, we have paid scant attention to another important question: how do the courts feel about all of this? Typically, they fluctuate radically from positions of total disinterest to extreme preoccupation. ${ }^{75}$ However, if we consider the path of U.S. Supreme Court litigation over the past seven years-from Barefoot $v$. Estelle (allowing a non-examining forensic

\footnotetext{
${ }^{70}$ McCormick, Involuntary Commitment in Ontario: Some Barriers to the Provision of Proper Care, 124 CAN. MED. A.J. 715, 717 (1981) (emphasis added).

${ }^{11}$ Saks, Expert Witnesses, Nonexpert Wimesses, and Nonwitness Experts, 14 LAW \& HUM. BeHav. 291, 294 \& n.2 (1990). See also M. Perlin, supra note 34, at 14-18.

${ }^{72}$ Appeibaum, supra note 57, at 228.

${ }^{73}$ Rogers, supra note 40, at 150. See also Anderten, Staulcup \& Grisso, On Being Ethical in Legal Places, 11 Prof. Psychology 764 (1980).

${ }_{74}$ See, e.g., J. RoBrtscher, supra note 29; J. RoBItscher, PursuIt of AGREEMENT: PsychutRY AND LAW (1966); S. HALLECX, suprá note 30; Halleck supra note 45; B. BURSTEN, supra note 51; J. Monahan, supra note 39; Rogers, supra note 40; Appelbaum, supra note 32; Appelbaum, supra note 57; Sadoff, Practical Ethical Problems of the Forensic Psychiatrist in Dealing with Attorneys, 12 BULL. AM. ACAD. PsYCHIATRY \& L. 243 (1984); Weinstock, Perceptions of Ethical Problems by Forensic Pychiatrists, 17 BulL. AM. ACAD. PsychIATRY \& L. 189 (1989); Weinstock, Controversial Ethical Issues in Forensic Psychiarry: A Survey, 33 J. Forensic SCI. 176 (1988): Weinstock, Ethical Concerns Expressed by Forensic Psychiatrists, 31 J. FoRENSIC SCT. 596 (1986). For a recent behavioral inquiry, see Hollien, The Expent Witness: Ethics and Responsibilities, 35 J. ForENSIC ScI. 1414 (1990).

${ }^{75}$ See Perlin, The Supreme Court, The Mentally Disabled Criminal Defendant, and Symbolic Values: Random Decisions, Hidden Rationales, or "Doctrinal Abyss"? 29 ARIz. L. REv. 1, 3 (1987) ("Like the moth to the flame, the [Supreme] Court remains irresistibly drawn to . . . cases [involving mentally disabled defendants and forensic testimony], espeically when they arise in the capital punishment setring.") (emphasis in original).
} 
expert to testify as to future dangerousness in a death penalty case on the basis of hypotheticals) ${ }^{76}$ through the competency for execution cases ${ }^{77}$ to the recent decision in Washington v. Harper (sharply limiting the right of a prisoner to refuse the imposition of unwanted psychotropic medications $)^{78}$-we find that, notwithstanding some expressions of concern by several justices (usually in dissent), ${ }^{79}$ the Supreme Court, institutionally, is profoundly underwhelmed by these imbalances, the resulting conflicts and the potential for serious exploitation of power ${ }^{80}$

This should not come as a major surprise. The Supreme Court's decisionmaking in the relevant areas has developed largely "out of consciousness," and the Court has regularly rejected all levels of psychodynamic explanation for personal behavior. ${ }^{81}$ In the course of his opinions, the Chief Justice has consistently revealed his discomfort in having to deal with questions involving mental disability, especially when they arise in forensic settings ${ }^{82}$ Myths and meta-myths saturate the relevant judicial opinions. ${ }^{83}$ In short, we cannot look to the Supreme Court, as currently constituted, to grant us much relief from the social dilemmas about which I have been speaking.

\section{THERAPEUTIC RELATIONSHIPS}

The public issues often at the center of the forensic relationship power struggle-the publicized insanity acquittal, the death penalty dangerousness hearing, and the operational impact of the implementation of the right to refuse treatment on an institutionalized population-are largely missing in the therapeutic relationship. It is thus perhaps easier to gloss over the underlying power imbalances that we still must reconcile in the traditional, dyadic relationship between the mental health professional and her client. For that reason, it may thus be even more important that we pay special attention to the subject.

In his monumental work, The Powers of Psychiatry, Jonas Robitscher was clear in his critique of the alleged neutrality or value-freedom of the therapeutic relationship. A whole "constellation of values-personal, economic, political, philosophical,

\footnotetext{
76463 U.S. 880, 903-04 (1983).

${ }_{77}^{77}$ See supra note 54.

${ }^{78}$ Washington v. Harper, 110 S. Ct. 1028, 1037-42 (1990) (state administrative rule adequately protected right to refuse of convicted prisoner); compare id. at 1052 (Stevens, J., dissenting) (sharply critiquing majority opinion for inappropriately blending state interests in "convenience prison administration" with individual's therapeutic need for medication); see $2 \mathrm{M}$. Perlin, supra note $54, \$ 5.64 \mathrm{~A}$, at $33-42$ (1990 pocket part).

${ }^{79}$ See generally Perlin supra note 75 , at $81-87$.

${ }^{\text {Bo }}$ But see Zinermon v. Burch, 110 S. Ct. 975, 986-90 (1990) (reflecting Supreme Court willingness to consider underlying issues in context of voluntary civil commitment admissions process).

${ }^{81}$ Perlin, supra note 75, at 98 (discussing Supreme Court's reading of cases involving mentally disabled criminal defendants); Perlin, supra note 52, at 731 (discussing this reading in the specific context of insanity defense jurisprudence); id. at 673-706 (critiquing Court's ambivalence toward mental health professionals and the mental health professions through the filter of cases involving mentally disabled criminal defendants).

${ }^{82}$ Id. at 713-30; Perlin, supra note 75, at 82-83. See, e.g., Ake v. Oklahoma, 470 U.S. 68, 83 (1985) (Rehnquist, J., dissenting) (right of indigent criminal defendant to psychiatric assistance to present insanity defense); Wainwright v. Greenfield, 474 U.S. 284, 297 (1986) (Rehnquist, J., concurring) (disallowing use of defendant's silence in response to Miranda waivers as evidence of sanity); Colorado v. Connelly, 479 U.S. 157, 163-69 (1987) (mental disability not a factor to consider in determining validity of Miranda waiver absent police misconduct).

${ }^{\text {83 }}$ Perlin, supra note 52, at 706-11 (discussing myths).
} 
therapeutic-determines the treatment relationship," is "foolish" for mental health professionals to claim that their disciplines are "objective and value free":

The purpose of the therapeutic encounter is to permit one person to have enough effect on another person to change behavior and personality, and such a situation is rife with values. ... The values that psychiatrists provide for their patients and for society are the most influential expressions of the great authority that psychiatry exerts. ${ }^{85}$

Seymour Halleck saw the power issue even more specifically, arguing that, by participating in individual psychotherapy, a patient "regularly experiences either a gain or a loss of power in relation to his family or friends," in the therapy encounter that favor conformity "tend to be the most powerful."

Here, Halleck and Robitscher were engaging primarily in a social critique rather than a legal one (although they both acknowledged the degree to which behavioral decisions by mental health professionals led to legal outcomes and implicated legal standards) ${ }^{88}$ But their concerns still help inform the way we must think about this topic. Issues of power permeate the therapeutic relationship, albeit in more subtle ways than they infect the forensic relationship. The fact that the therapeutic relationship takes place regularly hidden from public view (in direct opposition to the media saturation that sometimes accompanies forensic decision making ${ }^{89}$ should not obscure this fact.

Because the therapeutic relationship is a private one, and because therapy generally takes place behind closed doors, the rest of society remains somewhat in the dark as to what actually goes on, and as to what impact the underlying power imbalances have over what transpires. For better or worse, one major source of data is that of the reported caselaw: litigation is what happens, at least sometimes, when the therapeutic relationship is perceived as severely infected.

If we try to turn to this as our database, we must begin by confronting an important empirical reality. Notwithstanding the general perception of a "litigation explosion" (a perception that is deeply flawed on a variety of important levels), ${ }^{90}$ the reality is that the incidence of civil malpractice suits against mental health professionals remains substantially lower than rates for other medical specialities, ${ }^{91}$ a variance

\footnotetext{
${ }^{84} \mathrm{~J}$. ROBITSCHER, supra note 29, at 399.

${ }^{85}$ Id. at 400.

${ }^{86}$ S. HALlECX, supra note 30 , at 33.

${ }^{87}$ Id. at 33-34.

${ }^{88}$ See, e.g., S. HALLECK, supra note 30, at 139-46; J. ROBITSCHER, supra note 29, at 401-05; J. RoBITSCHER, supra note 74 , at $16-34$.

${ }^{89}$ On the impact of the media on the shaping of insanity defense jurisprudence, see Perlin, supra note 52 , at $617 \mathrm{n} .76,621-22 \mathrm{n} .101$, and sources cited therein.

${ }_{90}$ Compare Barton, Behind the Legal Explosion, 27 StAN. L. Rev. 567 (1975); Manning, Hyperlexis: Our National Disease, 71 Nw. U. L. REv. 767 (1977) (setting out myths), to Galanter, Reading the Landscape of Disputes: What We Know (And Think We Know) About Our Allegedly Contentious and Litigious Society, 31 UCLA L. REv. 4, 38-39 (1983); Felstiner, Abel \& Sarat, The Emergence and Transformation of Disputes: Naming, Blaming, Claiming . . ., 15 LAW \& Soc'y REv. 631, 652 (1984); Rottman, Tort Litigation in the State Cours: Evidence from the Trial Court Information Network, 14 STATE CT. J. 4 (Fall 1990) (setting out reality).

${ }^{91}$ See M. PERLIN, supra note 54, $\$ 12.02$, at 3-4, citing Slawson, The Clinical Dimension of Psychiatric Malpractice, 14 Psychiatric Annals 358, 363 (1984); see also, Slawson Psychiatric Malpractice: A Statewide Survey, 6 Bull. AM. Acad. Psychatry \& L. 58 (1978).
} 
that is reflected in the comparatively "minuscule" insurance rate increases in the mental health professions (as compared to other branches of health care) ${ }^{92}$

Many reasons have been offered to explain this low rate. Speculations have focused on the general reluctance of the tort law to provide remedies for emotional injuries, the difficulty in proving the applicable standard of care and the existence of a causal relationship between the breach of the standard and the alleged injury, the stigma that patients fear might result from making public their psychiatric history, the reluctance to sue as a result of a patient's emotional tie to the mental health professional and/or the patient's feeling that psychotherapy could not succeed without the therapist's full cooperation, the inability on the part of many patients either to formulate clear expectations for the result of their treatment or to assess the "success" of their results, the ability of trained mental health professionals to deal therapeutically with patient hostility and thus avoid suit, the frequency with which many patients see mental health professionals, and the fact that psychiatry and psychology remain somewhat enigmatic to a significant percentage of the trial bar. ${ }^{93}$

We are now learning some important data, as to why some patients choose to sue over the "violation of expectations" that leads to malpractice litigation. Recent empirical studies suggest that the decision to file suit is related positively to patient assertiveness, to the patient's ability to engage in strategic formulations, and to the involvement and discernment of a "broad audience network" (actors external to the relationship between dissatisfied patients and doctors), and is related negatively to such factors as the patient's evaluation (prior to the precipitating grievance) of the doctor's competence, to the doctor's show of concern for the patient's "state in life," and, interestingly, to the patient's degree of knowledge about the work of both health and legal professionals (i.e, those with greater knowledge about either, sue less). ${ }^{95}$

In addition, there is now some significant external evidence that this "most favored nation" status is now changing. In recent years, the law has become generally more receptive to allegations of emotional injury, ex-patients have openly and candidly discussed their treatment experiences (thus perhaps lessening the stigma of treatment for others), the "explosion" in litigation on behalf of the institutionalized mentally disabled has sensitized judges and litigators to some of the underlying substantive issues, and more has been learned about what happens empirically when

12 See Bonnie, Professional Liability and the Quality of Mental Health Care, 16 LAW MED. \& HeALTH CARE 229,229 (1988). For a recent overview of relevant issues, see Herzog, The Reform of Medical Liability:

Tort Law or Insurance, 38 AM. J. COMP. L. 99 (1990).

${ }_{93}$ M. PERIIN, supra note 54, \$12.02, at 4-5; see generally Fishalow, The Tort Liability of the Psychiatrist, 4 Bull. AM. ACAD. Psychitatry \& L. 191 (1975); Taub, Pychiatric Malpractice in the 1980's: A Look at Some Areas of Concem, 11 LAW MED. \& HeALTH CARE 97 (1983); Klein \& Glover, Psychiatric Malpractice, 6 INT'L J.L. \& PSYCHIATRY 131 (1983).

${ }^{94}$ See M. Silberman, "Law as Process: A Value-Added Model of the Mobilization of Law," paper presented at the annual meeting of the American Sociological Association (1977), manuscript at 3, as cited in May \& Stengel, Who Sues their Doctors? How Patients Handle Medical Grievances, 24 LAw \& Soc'Y REV. $105,106(1990)$.

${ }^{99}$ May \& Stengel, supra note 94, at 115-18. On the resolution choices that mark the process of transforma-

tion from grievance to law suit, see Felstiner, Abel \& Sarat, supra note 90, at 633-36.

${ }^{96} S_{6 e}$ Perlin, Institutionalization and the Law, in PsYchIATRIC SERVICES IN INSTITUTIONAL SETTINGS 75,
76 (American Hospital Association ed. 1978). 
certain treatments are employed. ${ }^{97}$ Yet, many of the explanations of the still-lower relative rate of litigation can still be traced to the power imbalances inherent in the therapeutic relationship: the stigma resulting from publicizing a "failed" therapy encounter, impact of the transference phenomenon on reluctance to sue, feelings of patient-generated self-blame for therapy "failures," and the skill with which many mental health professionals can sidestep hostility by deftly shifting the focus of therapeutic encounters. 98 .

Still as we know, important cases involving therapeutic relationships have been litigated. It is also likely that the public's use of the availability heuristic ${ }^{99}$ significantly inflates perceptions of both the frequency and the precedential impact of such cases. For both empirical and instrumental reasons, then, it is important that we look at some of these areas of litigation in an effort to evaluate the extent to which they are permeated by power imbalance issues. I want thus to consider briefly three specific problems that may stem from the sort of boundary violation ${ }^{100}$ that accompanies power imbalance: litigation based on improper treatment (including drug reactions), ${ }^{101}$ litigation based on improper sexual conduct and/or attempts to financially manipulate clients, ${ }^{102}$ and litigation that arises from perceived violations of confidentiality, especially with regard to the type of "third party" protection or warning that was present in the Tarsoff case. ${ }^{103}$

First, it should be intuitive that the improper administration of medication is a 'potential minefield." ${ }^{104}$ Beyond the problems posed by neurological side-effects such as tardive dyskinesia, ${ }^{105}$ liability issues can arise in a variety of medicationrelated settings:

[A] bsence of an adequate history, physical examination, and laboratory examination prior to treatment, prescription of a drug where it is not indicated, prescription of the wrong dosage, prescription of medication for inappropriately short or long time periods, failure to recognize, monitor or treat side-effects

\footnotetext{
${ }^{97} 3$ M. PERLIN, supra note 54, \$12.02, at 6-7; see also B. FURROW, MaLPRACTICE IN Psychiatry (1980); Wettstein \& Appelbaum, Legal Liability for Tardive Dyskinesia, 35 Hosp. \& Commun. Psychratry 992 (1984); Wettstein, Psychiatry and the Law, in Textrook of PsychiatRy 1059 (J. Talbott, R. Hales \& S. Yudofsky eds. 1988); Wettstein, Psychiatric Malpractice, in 8 RevIEW of PSYchIATRY 392 (A. Tasman, R. Hales \& A. Frances eds. 1989).

${ }_{98}$ On the correlative question of the duties that can be imposed on patients in the context of therapeutic relationships, see Beahrs, Legal Duties of Psychiatric Patients, 18 BUlL. Am. ACad. Psychiatry \& L. 189 (1990).

${ }^{99}$ For example, concrete and vivid information about a specific case overwhelms the abstract data upon which rational choices are usually made. see Rosenhan, Psychological Realities and fudicial Policies, 10 StaN. LAW. 10, 13-14 (1984); Perlin, supra note 34, at 987 n. 197; see generally Perlin, Psychodymamics and the Insanity Defense: "Ordinary Common Sense" and Heuristic Reasoning, 67 NEB. L. REV. 3, 12-14 (1990).

${ }^{100}$ The boundaries of patient-therapist relationships are discussed in 1 THE TECHNIQUES OP PsYcHOANALYTIC PSYCHOTHERAPY 206-208, 581 (R. D. Langs ed. 1973).

${ }^{10 i}$ See, e.g., Wettstein, Tardive Dyskinesia and Malpractice, 1 BeHavioral ScI. \& L. 85 (1983).

${ }^{102}$ See, e.g., Coleman, supra note 22.

${ }^{103}$ See, e.g., Note, The Psychotherapist's Calamity: Emerging Trends in the Tarasoff Doctrine, 1989 B.Y.U. L. REV. 261.

1043 M. PERLIN, supra note 54, $\$ 12.10$, at 34.

${ }^{105}$ See id. $\$ 12.11$, at 37-39.
} 
or toxicity failure to abate the possibility of drug reactions or interactions, and failure to consult with the necessary experts. ${ }^{106}$

While there still have been few decisions in this area, ${ }^{107}$ the scant litigation that has been reported reflects some of the issues inherent in power imbalances. For example, there have been instances of doctors who prescribed a 50-day supply of Valium without taking a medical history or checking the patient's medical records, ${ }^{108}$ who failed to change a prescription following his observation of side-effects and the onset of self-destructive behavior on the part of the patient, ${ }^{109}$ or who prescribed addictive drugs so as to help the patient see the nature of his addictive personality. ${ }^{110}$ It is not clear whether the therapists' actions stemmed simply from sloppy medical practice ("negligence" in the true sense of the word), whether they resulted from a failure to take patients' individual needs into account, or something else.

When one reads some of the cases in this area carefully, one can almost discern a pattern: the defendant-perhaps employing "typification",111__slots" his patients into certain categories, and prescribes a similar regimen for all. ${ }^{112}$ Such a pattern reflects precisely the kind of power imbalance that Robitscher and Halleck warned about. ${ }^{113}$

Second, the sexual misconduct cases ${ }^{114}$ are probably the most pernicious since (1) while there is no question that such behavior by a therapist is "always unethical," $" 115$ (2) surveys suggest that between $10 \%$ and $17 \%$ of therapists have engaged in such behavior with their clients, ${ }^{116}$ and (3) the fact settings by their very nature reflect a severe power imbalance. ${ }^{117}$ Three cases have been well publicized in this regard. In Roy $v$. Hartogs, ${ }^{118}$ the court upheld a damage award to a patient whose psychiatrist engaged in sexual intercourse with her, claiming that it was a legitimate part of therapy; in Zipkin $v$. Freeman, ${ }^{119}$ an award was upheld when the therapist persuaded his patient to swim with him in the nude, leave her husband, and invest her money in business ventures that he controlled; in Landau $v$. Werner, ${ }^{120}$ a verdict Was similarly affirmed when a therapist, after explaining the transference phenome-

\footnotetext{
Tor Wettstein, supra note 101 , at 89 .

${ }_{109}^{107}$ See Klein \& Glover, supra note 93, at 135.

${ }_{109}$ atkins v. United States, 589 F. 2d 214 (5th Cir. 1979).

${ }_{110}$ Hale v. Portsmouth Receiving Hosp., 44 Ohio Misc. 90, 338 N.E.2d 371 (Ct. Cl. 1975).

${ }_{111}^{110}$ Rosenfeld v. Coleman, 19 Pa. D. \& C.2d 635 (Ct. C.P. 1959).

${ }^{111}$ See Perlin, supra note 99, at 29-30, discussing the self-fulfilling prophecies inherent in typification; see generally Van Zandt, Commonsense Reasoning, Social Change, and the Law, 81 Nw. U. L. REv. 894, 913 (1987).

${ }^{112}$ Similar "I always do it this way" issues are raised in Mills, Psychiatric Malpractice, 7 FAIR OAKS

Hosp. Psychiatric Newsl., Sept. 1990, at 1,.3; Schuchman \& Wilkes, Dramatic Progression Against

Depression, N.Y. Times Magazine, Oct. 7, 1990, at 12.

${ }^{14}$ See J. ROBITSCHER, supra note 29 ; S. HALLECK, supra note 30.

115 See 3 M. PERLIN, supra note 54 at $\$ 12.09$.

${ }_{116}$ Klein \& Glover, supra note 93, at 138.

See, e.g., B. Furrow supra note 97, at 34 (10\%); R. Corren, Malpractice; A Gutde for MENTAL Hralth Professions 88-89 (1979) (same); Dresset v. Board of Medical Quality Assurance, $130 \mathrm{Cal}$.

App.3d 506, 181 Cal. Rptr. 797, 800 (1982) (17\%).

${ }_{118}^{17}$ See Coleman, supra note 22, at 96, and supra text accompanying note 22.

${ }^{1 / 8} 81$ Misc. 2d 350, 366 N.Y.S.2d 297 (Civ. Ct, 1975), modified, 85 Misc. 2d 891, 381 N.Y.S.2d

587 (Sup. Ct. 1976).

${ }_{120} 436$ S.W.2d 753 (Mo. 1968).

105 Sol. J. 1008 (C.A. 1961).
} 
non ${ }^{121}$ to a patient who had told him she had fallen in love with him, began to date the patient and discussed the possibility of vacationing together.

In all of these instances-as well as others less notorious ${ }^{122}$ - the patient remains vulnerable to and susceptible to the influence and suggestion of the therapist. ${ }^{123}$ As time continues, as revelations of similar improper sexual contacts increase, and as we confront the reality that the vast majority of therapists self-report a feeling of sexual attraction to their clients, ${ }^{124}$ we can expect a proliferation of "sexual misconduct" litigation. In virtually every instance, the power imbalances inherent in the therapeutic relationship will be at the core of the litigation.

Finally, the confidentiality cases must be seen through two different prisms: those cases that arise from a breach of a mental health professional's failure to maintain secrecy regarding a disclosure made to him directly by a patient (about the patient herself), ${ }^{125}$ and those that stem from an inquiry into the professional's duty to protect others as a result of information given by the patient in which there is a question as to whether or not a third party might be in danger, the so-called Tarasoff exception. ${ }^{126}$

The first grouping of cases implicate statutory rights (in those jurisdictions where there is an operative psychotherapist-patient privilege), ${ }^{127}$ contractual rights ${ }^{128}$ and constitutional rights (where the right to privacy is given such content). ${ }^{129}$ The right to confidentiality, of course, is not absolute. In addition to the Tarasoff cases (where there is a judicially or legislatively imposed duty to warn or protect a third party of potential danger), ${ }^{130}$ there are exceptions inherent in the forensic relationship, ${ }^{131}$ in cases where the patient puts his mental state in issue affirmatively in litigation, ${ }^{132}$ and in cases where there is a conflict between confidentiality and a police power

${ }^{121}$ See Decker v. Fink, 47 Md. App. 202, 422 A.2d 389, 391 (1980):

Inherent in the transference neurosis is the development of a strong dependence by the patient upon the analyst and an extraordinary faith and trust in him which may develop into a love relationship and which can deprive the patient of her independent judgment and ability to distinguish the reality of her interaction with the analyst and vice versa.

The "transference neurosis" is explained and discussed in R. BALSAM \& A. BALSAM, BECOMING A Psychotherapist: A Clinical Primer 64-73 (1974).

${ }^{122}$ See also Anclote Manor Found. v. Wilkerson, 263 So.2d 256 (Fla. Dist. Ct. App. 1972); Cotton v. Kambly, 101 Mich. App. 537, 300 N.W.2d 627 (1980); Mazza v. Huffaker, 61 N.C. App. 170, 300 S.E.2d 833 (1983); Andrews v. United States, 732 F.2d 366 (4th Cir. 1984); Matter of Schroeder, 415 N.W.2d 436 (Minn. Ct. App.), rev. den., (Jan. 23, 1988); Block v. Ambach, 140 A.D.2d 814, 528 N.Y.S.2d 204 (1988), aff'd, 73 N.Y.2d 323, 537 N.E.2d 1181, 540 N.Y.S.2d 6 (1989).

${ }^{123}$ Decker, 422 A.2d at 391 . See also Note, Parient-Therapist Sexual Relations: Professional Services Rendered? A Case Comment on Doe v. Srvift, 14 LAW \& PsYCHOLOGY REV. 87 (1990).

${ }^{124}$ Solursh \& Solursh, Sex and Therapy, Psychiat. News, Oct. 5, 1990, at 31 (letter to the editor).

${ }^{125}$ See 3 M. PerLIN, supra note 54, at $\$ 12.37,105-09$.

${ }^{126}$ See id., at $\$ \$ 13.05-.21$.

${ }^{127}$ See, e.g., Smith, Medical and Psychotherapy Privileges and Confidentiality: On Giving With One Hand And Removing With the Other, 75 KY. L. REv. 473(1986-87); D. SHUMAN, PsychIATRIC AND PsYchologICAL EVIDENCE \$\$10.01-.12 (1986).

${ }_{128}$ See Eger, Psychotherapists' Liability for Extrajudicial Breaches of Confidentiality, 18 ARIz. L. REV. 1061, 1065-77 (1976).

${ }^{129}$ Cutter v. Brownbridge, 183 Cal. App.3d 836, 228 Cal. Rptr. 545 (1986).

${ }^{130}$ See Tarasoff v. Board of Regents of Univ. of Cal., 17 Cal.3d 425, 551 P.2d 334, 131 Cal. Rptr. 14 (1976).

131 See supra Part II.

${ }^{132}$ See, e.g., In re Lifschutz, 2 Cal.3d 415, 467 P.2d 557, 84 Cal. Rptr. 829 (1970); Caesar v. Mountanos, 542 F.2d 1064 (9th Cir. 1976). 
statute (such as one governing civil commitment or child abuse reporting). ${ }^{133}$ Nevertheless, the policy's rationale rests finally on a power issue: disclosure of confidential communications might well "deter persons from seeking needed assistance, or from making the full disclosure on which diagnosis and treatment depends."134

The Tarasoff paradigm actually more closely parallels the issues raised in considering forensic relationships. Since courts and legislatures have carved out a confidentiality exception, the question remains: how will therapists respond to the externally imposed duty to breach confidentiality? A variety of sensitive solutions has been suggested. Loren Roth and Alan Meisel, for instance, have listed five guidelines to govern Tarasoff situations: (1) prudence to avoid being "stampeded" into giving unnecessary warnings; (2) provision of information as to the limits of confidentiality prior to the entry into the therapeutic relationship; (3) the use of various "social and environmental manipulations" prior to being forced to compromise confidentiality (such as bringing third parties into the therapeutic setting); (4) obtaining patients' permission (wherever possible) prior to disclosure of confidential information, and disclosing such information in the patient's presence; and (5) assessing any such intervention in light of its potential impact on future therapy and in light of the likelihood that it will be successful in preventing future violence. ${ }^{135}$ Again, these suggestions implicitly reflect the problems raised by power imbalances in the therapeutic/forensic relationship.

\section{CONCLUSION}

Having said this, it is necessary to also acknowledge some extraordinarily important additional truths:

- Courts are suspicious of and generally reject psychodynamic explanations of interpersonal behavior, as being inherently dissonant with the "free will" basis of the criminal justice and tort systems. ${ }^{136}$

-Much legal decisionmaking can best be explained by (1) a study of the types of simplifying heuristics that frequently lead to distorted and systematically erroneous decisions through ignoring or misusing of rationally useful information, ${ }^{137}$ and (2)

${ }^{133}$ See, e.g., Commonwealth ex rel. Platt v. Platt, 266 Pa. Super, 276, 404 A.2d 410 (1979) (commitment);

Miller \& Weinstock, Conflict of Interest Between Therapist-Patient Confidentiality and the Duty to Report Sexual Abuse of Children, 5 BEHAVIORAL SCI. \& L. 161 (1987). On the impact of an AIDS diagnosis on the right to confidentiality, see, e.g., Note, AIDS: Establishing a Physician's Duty to Wam, 21 RUTGRRS L.J. 645 (1990); Weiss, AIDS: Balancing the Physician's Duty to Warn and Confidentiality Concerns, 38

EMORY L.J. 299 (1989). Compare supra text accompanying note 64 (on the role of social bias in the physician's decision as to whether or not to breach confidentiality).

${ }_{134}$ Simek v. Superior Court, 117 Cal. App.3d 169, 172 Cal. Rptr. 564, 569 (1981).

${ }^{135}$ Roth \& Meisel, Dangerousness, Confidentiality, and the Duty to Wam, 134 AM. J. Psychiatry 508,

509-511 (1977). For an alternative methodology, see Appelbaum, Tarasoff and the Clinician: Problems in Fulfiling the Duty to Protect, 142 AM. J. PsYCHATRY 425, 426-27 (1985). For other alternative solutions, see 3 M. PERLIN supra note 54, $\$ 13.20$, at 181-82 n. 422, and id., $\$ 13.20$, at 20 n. 422 (1990 pocket part) (listing sources).

${ }_{137}^{13}$ See generally Perlin, supra note 52, at 673-88.

cation. generally Perlin, supra note 99, at 12-22; Saks \& Kidd, Human Information Processing and Adjudication: Trial By Heuristics, 15 LAW \& Soc'y REv. 123 (1980-81). 
an examination of the way that "ordinary common sense" unconsciously animates decisionmakers. ${ }^{138}$

-Judges are profoundly teleological in their use of social science and behavioral evidence in their decisionmaking, a factor that tends to further debase and trivialize scientific research, data and discourse. ${ }^{139}$

-Jurors are overwhelmingly ambivalent about all of the underlying concepts: the role of mental health expert testimony in the court process, mental disability as an animating explanation for behavior, the efficacy of therapy, the proper balance that must be struck between professional autonomy, public safety and privacy, and jurors' decisionmaking similarly reflects the use of heuristic reasoning devices and "ordinary common sense." "140

-As a result of these conflicts and ambivalences, legal decisionmakers, like the rest of us, exhibit cognitive dissonance (the reinterpretation of information and experience that conflicts with their internally accepted or publicly stated beliefs so as to avoid the unpleasant state that such inconsistencies produce ${ }^{141}$ in the way they deal with the substantive issues under consideration.

These final thoughts are not meant to be nihilistic, but to simply accentuate the difficulty of resolving the underlying issues. We must consciously "unpack the myths"142 and "strip the facade" 143 from the stereotypical ways that vivid, heuristic evidence is presented ${ }^{144}$-in legal forums, in mental health forums and in public forums-to consider the power imbalance issues that underlie each of these relationships. This must be done consciously and openly if we are to illuminate-and attempt to resolve- the core questions that concern us.

\footnotetext{
${ }^{138}$ See generally Sherwin, Dialects and Dominance: $A$ Study of Rhetorical Fields in Confessions, 136 U. P.A. L. REv. 729 (1988); Perlin, supra note 99, at 22-39; see also Newman, $A$ Tale of Two Cases: Reflections on Psychological and Institutional Influences on Child Custody Decisions, 34 N.Y.L. ScH. L. REV. 661, 669 (1989).

${ }^{139}$ M. Perlin, supra note 34, manuscript at 18-22; Perlin, supra note 99, at 61-69; Appelbaum, The Empirical Jurisprudence of the United States Supreme Court, 13 AM. J. L. \& MED. 335, 341 (1987).

${ }^{140} \mathrm{M}$. Perlin, supra note 34, manuscript at 22-23; Perlin, supra note 99, at 39-53; Gunn, An English Psychiatrist Looks at Dangerousness, 10 BULL. Ax. ACAD. PsYCHIATRY \& L. 143, 147 (1982).

${ }^{141} M$. Perlin, supra note 34, manuscript at 26-27; Winick, supra note 43, manuscript at 62 , and id. at 140 (citing sources); see generally L. FEsTINGER, A THEORY OR COGNITIVE DissONANCE (1957).

${ }^{142}$ See Perlin, supra note 52.

${ }^{143}$ See Perlin, supra note 34.

${ }^{144}$ See Perlin, Competency, supra note 34; M. PeRLIN, supra note 34, manuscript at 54.
} 